\title{
Soil Chemical Properties under Conservation Agriculture and Cereal- Based Cropping System in Eastern Tarai of Nepal
}

\author{
Shukra Raj Shrestha ${ }^{1 @}$, Jiban Shrestha ${ }^{2}$, Sanjeet Kumar Jha ${ }^{3}$, Dinesh Khadka ${ }^{4}$, Prakash Paneru ${ }^{5}$ and \\ Pankaj Gyawaly ${ }^{6}$
}

${ }^{1}$ Regional Agricultural Research Station, NARC, Tarahara, Sunsari, Nepal; @: shukrarajshrestha@gmail.com ORCID: https://orcid.org/0000-0001-9504-0504

${ }^{2}$ Agriculture Botany Division, NARC, Khumaltar, Lalitpur, Nepal; jibshrestha@gmail.com

${ }^{3}$ Agriculture Engineering Division, NARC, Khumaltar, Lalitpur; spnepali@ gmail.com

${ }^{4}$ Soil Science Division, NARC, Khumaltar, Lalitpur; dinesh.khadka92@gmail.com

${ }^{5}$ National Rice Research Program, Hardinath, Dhanusha, Nepal; paneru2047@gmail.com

${ }^{6}$ Agronomy Division, NARC, Khumaltar, Lalitpur; pankajgyawaly@gmail.com

\section{Received 15 Oct 2019, Revised 5 Dec 2019, Accepted 14 Feb 2020, Published 17 March 2020 \\ Scientific Editors: Dinesh Adhikari, Shree Prasad Vista \\ Copyright $(2020$ NARC. Permits unrestricted use, distribution and reproduction in any medium provided the original work is properly cited. \\ The authors declare that there is no conflict of interest.}

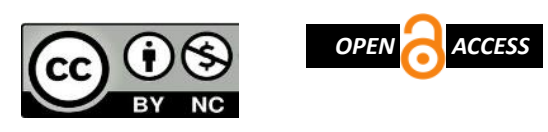

Licensed under the Creative Commons AttributionNonCommercial 4.0 International (CC BY-NC 4.0)

\section{ABSTRACT}

Field experiments were conducted for four years (2014-2017) at five locations namely Salbani, Bhokraha, Simariya, Bhaluwa and Kaptanganj of Sunsari district to assess the changes in soil chemical properties under conservation agriculture (CA)-based practices in two cropping systems namely ricekidney bean-maize at Salbani and rice-wheat at rest of the locations. In rice-wheat cropping system, there were four treatments: (1) conventional tillage (CT) for rice transplantation and subsequent wheat sowing, (2) conventional tillage rice transplantation followed by zero tillage (ZT) wheat, (3) unpuddled rice transplantation followed by zero tillage wheat, (4) zero tillage in both rice and wheat. Similarly, in rice-kidney bean-maize cropping system, there were four treatments; (1) conventional tillage for rice transplantation and sowing of both kidney bean and maize, (2) conventional tillage rice transplantation followed by zero tillage in both kidney bean and maize, (3) unpuddled rice transplantation followed by zero tillage in both kidney bean and maize, (4) zero tillage in all three crops. Soil samples were taken at initial and every year after rice harvest.The soil samples were analyzed for total nitrogen, available phosphorus, available potassium, $\mathrm{pH}$ and soil organic matter.Total nitrogen $(\mathrm{N})$ showed a slightly decreasing trend in the first three years and showed a slight increase at the end of experiment under ZT in all locations. The total $\mathrm{N}$ under ZT changed from 0.12 to $0.13 \%, 0.05$ to $0.06 \%, 0.10$ to $0.12 \%, 0.11$ to $0.08 \%$ and 0.09 to $0.13 \%$ in Salbani, Bhokraha, Simariya, Bhaluwa and Kaptanganj, respectively. All locations showed the positive values of available potassium; Salbani revealing considerable change of 64.3 to $78.5 \mathrm{mg} / \mathrm{kg}$ in CT while 68.4 to $73.3 \mathrm{mg} / \mathrm{kg}$ in ZT condition. The treatment where rice was transplanted in unpuddled condition and zero tilled to wheat, had a mean value of available phosphorus and potassium as 87.3 and $81.9 \mathrm{mg} / \mathrm{kg}$ respectively. Soil $\mathrm{pH}$ ranged from 4.8 to 7.1 in CT while it was 5.2 to 6.8 in ZT across the locations. The change in soil organic matter in CT of all locations except Salbani was narrower as compared to ZT.

Keywords: Cropping systems, Eastern Tarai, Soil chemical properties, Tillage practices

सारांश

सन् २०१४ मे देखि २०१७ नोभेम्बर सम्म सुनसरी जिल्लाको पाँच वटा स्थानहरु : सालबनी, भोक्राहा, सिमरिया, भलुवा र कप्तानगंजमा किसानको खेतमा संरक्षण कषिको अभ्यासहरुमा आधारित रही बिभिन्न बाली प्रणलीहरुमा परिक्षणहरु संचालन गरियो। यस क्षेत्रीय कृषि अनुसन्धान केन्द्र, तरहराले उक्त परिक्षणहरु गरेको थियो। भोक्राहा, भलुवा, सिमरिया र कप्तानगंजमा धान-गहुँ र सालबनीमा धान-राजमा-मकै बाली प्रणालीमा परिक्षणहरु गरिएको थियो। प्रत्येक स्थानमा ३ वटा किसानहरुको खेतमा $\checkmark$ वटा संरक्षण कषिमा आधारित तरिकाहरु अपनाई परिक्षणहरु गरिदा प्रत्येक तरिका $४ ० ०$ वर्ग मिटरको क्षेत्रफलमा रहेको थियो। परिक्षण सुरु हुनु भन्दा पहिले प्रयोगशाला जाँचको लागि माटोको नमुना $\checkmark$ वटै तरिका अन्तर्गतको र प्रत्येक बर्ष धान काटेपछि, माटोमा निहित जम्मा नाइट्रोजन,उपलब्ध फस्फोरस र पोटासियम, पी.एच र प्राड्द्वारिक पदार्थको लागि जाँच गरियो। धान-गहुँ बाली प्रणाली अन्तर्गत पहिलो तरिका (टी १) : परम्परागत खनजोत गरी धान रोप्ने-परम्परागत खनजोत गरी गहुँ छर्ने, दोस्रो (टी २) : परम्परागत खनजोत गरी धान रोप्ने-गहुँमा शुन्य खनजोत, तेस्रो (टी ३) : जमिनलाई नहिल्याई मेसिनले धान रोप्ने-गहुँमा शुन्य खनजोत र 
चौथो (टी ४): धानमा शुन्य खनजोत-गहुँमा शुन्य खनजोत । यसैगरी धान-राजमा-मकै बाली प्रणाली अन्तर्गत अपनाईएको ४ तरिकाहरु: पहिलो (टी १) : परम्परागत जोताई गरी धान रोप्ते-परम्परागत तरिकाले राजमा छर्ने-परम्परागत तरिकाले मकै छर्ने ,दोस्रो (टी २) : परम्परागत खनजोत गरी धान रोप्ने-राजमामा शुन्य खनजोत-मकैमा शुन्य खनजोत, तेस्रो (टी ३) : जमिनलाई नहिल्याई मेसिनले धान रोप्ते-राजमामा शुन्य खनजोत-मकैमा शुन्य खनजोत र चौथो (टी ४) : धानमा शुन्य खनजोत-राजमामा शुन्य खनजोत-मकैमा शुन्य खनजोत। सबै स्थानहरुमा पुर्ण रुपले शुन्य खनजोत गरिएको प्लटमा माटोमा निहित नाइट्रोजन पहिलो ३ बर्षमा थोरै मात्रामा घट्दै गईरहेको तर अन्तिम बर्षमा बढ़को र भलुवामा मात्र यो पोषक तत्व ॠणात्मक रहेको पाईयो । पुर्ण रुपमा शुन्य खनजोत गरिएको प्लटमा परिक्षण अवधिभर नाईट्रोजन तत्व बिभिन्न स्थानहरु सालबनी, भोक्राहा, सिमरिया, भलुवा र कप्तानगंजमा कमश : 0.9 दखि 0.9 ₹, 0.0 देखि $0.0 ६, 0.90$ देखि 0.9 , 0.99 देखि $0.0 द$ र $0.0 ९$ दखि 0.9 प्रतिशत ले परिवर्तन भएको पाईयो। सबै स्थानहरुमा उपलब्ध पोटासियमको मात्रा परिक्षण अवधिभर धनात्मक रहेको र खासगरी सालबनीमा परम्परागत खनजोत र शुन्य खनजोत गरिएको प्लटहरुमा ऋमश: ६४.३ देखि ७६.५ र ६६.४ देखि ७३.३ मी.ग्रा प्रति के.जी भेटियो। धान-गहुँ बाली प्रणाली अन्तर्गत नहिल्याई मेसिनले रोपेको धान र गहुँमा शुन्य खनजोत गरिएको प्लटमा उपलब्ध फस्फोरस र पोटासियमको औसत मात्रा ऋमश : ६६.३ र ६ १.९ मी.ग्रा प्रति के.जी रहेको पाइयो। सबै स्थानहरुमा परम्परागत तरिका अपनाइएको प्लटहरुको माटोको पी.एच अन्तर ४.५ देखि .9 र शुन्य खनजोत गरिएको प्लटहरुको पी.एच अन्तर $4 . २$ देखि ६.५ भेटियो। परम्परागत तरिका अपनाइएको प्लटहरुमा प्राड्द्धारिक पदार्थको अन्तर सालबनी बाहेकको सबै स्थानहरुमा शुन्य खनजोत गरिएको प्लटहरु भन्दा कम पाईयो।

\section{INTRODUCTION}

Soil parameters like organic matter, soil $\mathrm{pH}$ and plant nutrients determine the capacity of soil to sustain crops productivity. Conservation agriculture (CA) and crop diversification or intensification may change these soil parameters positively or negatively, which eventually affects long-term sustainability (Sinha et al 2019). Key soil parameters such as soil organic matter, pH and plant nutrients reflect both inherent and dynamic soil properties, and are governed by physical, chemical and biological processes in soil (Karlen et al 2003). These parameters are differently affected by Conservation Agriculture based Sustainable Intensification (CASI) practices as by conservation tillage practices (Choudhary et al 2018). Soil organic matter affects soil physical properties such as soil aggregation, chemical properties such as nutrient sinks and sources and their transformations, and biological properties such as microbial activity (energy and nutrient supply and physical habitat) for nutrient cycling (Gathala et al 2017). Soil pH is the single most dominant factor, which affects a range of chemical and biological processes and soil functions (Karlen et al 2003). Further, plant available N, $\mathrm{P}$ and $\mathrm{K}$ are major nutrients that affect crop productivity and the long-term sustainability of a farming system (Wanjari et al 2004).

Proper application of conservation tillage practices provokes a number of effects, which helps to overcome soil degradation and to slowly improve the soil quality and aids in retention of soil moisture (Karki and Shrestha 2015). Rice-wheat system is largely practiced on the low land ecosystem of Sunsari district where heavier soil texture, excessive soil moisture, and late rice harvest lead to higher production cost and delays in wheat planting (RARS 2016). Soil puddling is the most common practice for transplanting rice. It involves plowing and planking in standing water and results in the dispersion of aggregate clay to muddy suspension. Because of the implements used the soil pores are sealed by dispersed clay, a dense, impervious layer is formed at the plow sole (Mandal et al 2015). This compacted subsurface layer reduces percolation and nutrient losses, facilitates submergence (which helps control weeds), and created the reduced conditions favorable for rice to grow. Puddling and the compacted sublayer adversely affect the succeeding crop, however by restricting root growth, and decreasing porosity, water retention, infiltration and soil aggregate size. The traditional method of wheat establishment involves excessive tillage which is painstaking, time and energy consuming that further leads to poor plant stand and late planting (Hobbs and Gupta 2004). It is observed that soil erosion is accelerated due to excessive tillage. After realizing the negative effects of continuous excessive tillage, it is realized that the present practice of excessive tillage in crop production is not economical as well as not sustainable. Annual average nutrient loss from soils is rising. In South Asia, the cost of different forms of land degradation - such as loss of soil structure leading to nutrients loss and erosion, compaction and formation of surface crusts, is estimated at US\$10 billion a year (FAO 2000).

Eastern Tarai region of Nepal has a dominance of rice-wheat and rice-maize cropping system but the widespread stagnation and occasional decline in productivity of this rice-based cropping system has 
been observed in many parts of this region including Sunsari district (RARS 2016). Due to low levels of mechanization, high labour requirements and the high costs of irrigation and labour, overall production costs are high and farm profits are low (Gathala 2018). In order to sustainably achieve food security for, and improve the livelihoods of the predominantly impoverished rural people in the EGP, a project entitled 'Sustainable and resilient farming systems intensification-SRFSI in eastern Gangatic plains' was initiated since 2014 in different districts of three countries-Bangladesh, India and Nepal (Islam et al 2019). As a component of a sustainable and resilient farming systems intensification research program, farmer-participatory on-farm trials were conducted in five locations of Sunsari district namely Salbani, Bhokraha, Simariya, Bhaluwa and Kaptanganj introducing different CASI practices - ZT, crop residue retention and intensified crop rotations comparing to a CT practice on Inceptisols between 2014 to 2017. Since the activities were executed in five locations of Sunsari district, monitoring soil health isssues was felt necessary basically to know the response of different CA-based practices on soil properties so the appropriate remedial action can be taken to reduce crop yield losses as well as adverse impacts on soil health and the environment. The objective of this study were to assess the soil chemical properties: soil organic matter, soil $\mathrm{pH}$, total nitrogen, available $\mathrm{P}$ and $\mathrm{K}$ following the introduction of CASI practices in continuous ZT, unpuddled and conventional conditions in rice-wheat and rice-kidneybean-maize cropping system during four years.

\section{MATERIALS AND METHODS}

\section{Experimental sites}

Field trials were conducted in five locations namely Salbani, Bhokraha, Simariya, Bhaluwa and Kaptanganj of Sunsari district. The initial soil samples were collected before setup of trial in May 2014. Then after, soil samples were taken once in a year just after rice harvest in November. The soil samples of upper layer $(0-15 \mathrm{~cm}$ depth) were collected from each treatment. The soil samples were examined for total nitrogen, available phosphorus, available potassium, $\mathrm{pH}$ and soil organic matter (Table 1). In Salbani and Bhokraha the experiment plots possess soil textures: Sandy loam and Silty clay loam. Silty clay loam and Clay loam were the soil textural class in Simariya and Bhaluwa. Like wise, Sandy loam was soil texture existed in Kaptanganj where field trials were conducted.

Table 1. Parameters and methods adopted for the laboratory analysis at RARS, Tarahara and Soil Science Division, Khumaltar

\begin{tabular}{lll}
\hline SN & Parameter & Method \\
\hline 1 & pH & Potentiometric 1:2 (Jackson 1973) \\
\hline 2 & Soil Organic Matter $(\%)$ & Walkley and Black (Walkley and Black 1934) \\
\hline 3 & Total N $(\%)$ & Kjeldahl Digestion (Bremner and Mulvaney 1982) \\
\hline 4 & Available $\mathrm{P}_{2} \mathrm{O}_{5}(\mathrm{mg} / \mathrm{kg})$ & Olsen (Olsen et al1954) \\
\hline 5 & Available $\mathrm{K}_{2} \mathrm{O}(\mathrm{mg} / \mathrm{kg})$ & Ammonium acetate extraction method (Jackson 1967) \\
\hline
\end{tabular}

\section{Treatments details}

Four crop establishment methods (treatments) were designed and conducted in three farmers' field in all the selected locations (Table 2). The total size of the experimental plot was $1600 \mathrm{~m}^{2}$ with each treatment assigned in $400 \mathrm{~m}^{2}$. In rice-wheat cropping system, first treatment (T1): (conventional tillage rice transplantation-conventional tillage wheat) was traditional method (farmers' practice) of crop establishment to both crops. In second treatment (T2): (conventional tillage rice transplantationzero tillage wheat) rice was traditionally cultivated whereas wheat was sown through tractor operated zero-till seed drill machine. In third treatment (T3): (unpuddled rice transplantation-zero tillage wheat) rice was transplanted by rice transplanter machine whereas wheat seeds were sown by machine. Fourth treatment (T4): (zero tillage direct seeded rice-zero tillage wheat) was executed with zero/minimum tillage where seeds of both crops were sown through zero tillage machine. In ricekidney bean-maize cropping system in Salbani, four treatments were used. First treatment (T1): (conventional tillage rice transplantation-conventional tillage kidney bean-conventional tillage maize), second treatment (T2): (conventional tillage rice transplantation-zero tillage kidney bean-zero tillage maize), third treatment (T3): (unpuddled rice transplantation-zero tillage kidney bean-zero tillage maize) and fourth treatment (T4): (zero tillage rice-zero tillage kidney bean-zero tillage maize). The tillage practices to all crops in detail were described in Table 3. 
Table 2. Details of treatments (tillage practices) for field trials at Sunsari district (2014-2017)

\begin{tabular}{|c|c|c|c|c|c|}
\hline Location & $\begin{array}{l}\text { Number } \\
\text { of fields }\end{array}$ & $\begin{array}{l}\text { First treatment } \\
\text { (T1) }\end{array}$ & $\begin{array}{l}\text { Second treatment } \\
\text { (T2) }\end{array}$ & $\begin{array}{l}\text { Third treatment } \\
\text { (T3) }\end{array}$ & $\begin{array}{l}\text { Fourth treatment } \\
\text { (T4) }\end{array}$ \\
\hline Salbani & 3 & CTTPR-CTKB-CTM & $\begin{array}{l}\text { CTTPR-ZTKB- } \\
\text { ZTM }\end{array}$ & UPTPR-ZTKB-ZTM & ZTDSR-ZTKB-ZTM \\
\hline Bhokraha & 3 & CTTPR-CTW & CTTPR-ZTW & UPTPR-ZTW & ZTDSR-ZTW \\
\hline Simariya & 3 & CTTPR-CTW & CTTPR-ZTW & UPTPR-ZTW & ZTDSR-ZTW \\
\hline Bhaluwa & 3 & CTTPR-CTW & CTTPR-ZTW & UPTPR-ZTW & ZTDSR-ZTW \\
\hline Kaptanganj & 3 & CTTPR-CTW & CTTPR-ZTW & UPTPR-ZTW & ZTDSR-ZTW \\
\hline
\end{tabular}

Table 3. Description of treatments (tillage practices) on different crops in five locations of Sunsari district Tillage Rice Wheat Kidney bean Maize

Practices

\begin{tabular}{|c|c|c|c|c|}
\hline $\mathrm{CT}$ & $\begin{array}{l}\text { Single dry tillage operation by } \\
\text { rotavatar or disk harrow: one chas ( } 2 \\
\text { months after wheat harvest and a } \\
\text { week after maize harvest in R-W and } \\
\text { R-M cropping system respectively). } \\
\text { After about } 15 \text { days conventional } \\
\text { tillage with } 2 \text { passes (chas) by } 4 \mathrm{~W} \\
\text { tractor operated cultivator followed by } \\
\text { planking and levelling. } 25-30 \text { days old } \\
2-3 \text { seedlings transplanted at } 20 \times 20 \\
\text { cm plant-hill spacing. }\end{array}$ & $\begin{array}{l}\text { Seeds and } \\
\text { fertilizers/manu } \\
\text { res broadcasted } \\
\text { and a single } \\
\text { pass of } \\
\text { rotavatar. }\end{array}$ & $\begin{array}{l}\text { After rice } \\
\text { harvest } \\
\text { conventional } \\
\text { tillage with } 2 \\
\text { passes by } 4 \mathrm{~W} \\
\text { tractor operated } \\
\text { rotavatar } \\
\text { followed by } \\
\text { seeding at } 15 \mathrm{x} \\
25 \mathrm{~cm} \text { plant- } \\
\text { row spacing. }\end{array}$ & $\begin{array}{l}\text { After rice harvest single } \\
\text { conventional tillage with } \\
\text { single pass by } 4 \mathrm{~W} \text { tractor } \\
\text { operated rotavatar/cultivator. } \\
\text { After } 7-9 \text { days conventional } \\
\text { tillage with single pass by } \\
4 \mathrm{~W} \text { tractor operator } \\
\text { cultivator followed by } \\
\text { broadcasting of fertilizers. } \\
\text { Single conventional tillage } \\
\text { with single pass and } \\
\text { planking; maize dibbled } \\
\text { manually at } 60 \times 20 \mathrm{~cm} \text { line- } \\
\text { plant spacing at } 4-6 \mathrm{~cm} \\
\text { depth. }\end{array}$ \\
\hline $\mathrm{ZT}$ & $\begin{array}{l}\text { DSR sown with } 4 \mathrm{~W} \text { tractor operated } \\
\text { ZT-Multi crop planter with fluted } \\
\text { roller and/or inclined plate seed meter } \\
\text { in a single operation after proper } \\
\text { calibration. }\end{array}$ & $\begin{array}{l}\text { Seeds were } \\
\text { sown by ZT- } \\
\text { Multi crop } \\
\text { planter in a } \\
\text { single operation } \\
\text { after proper } \\
\text { calibration. }\end{array}$ & $\begin{array}{l}\text { After harvest of } \\
\text { rice, seeds were } \\
\text { sown by ZT- } \\
\text { Multi crop } \\
\text { planter in a } \\
\text { single } \\
\text { operation. }\end{array}$ & $\begin{array}{l}\text { Maize seeds sown with } \\
\text { residual moisture (or with } \\
\text { supplemental irrigation if no } \\
\text { rains) with } 4 \mathrm{~W} \text { tractor } \\
\text { operated ZT-Multi crop } \\
\text { planter with fluted roller } \\
\text { and/or inclined plate seed } \\
\text { meter in a single operation. }\end{array}$ \\
\hline UPTPR & $\begin{array}{l}\text { A 4-row walking type rice } \\
\text { transplanter (Model: } 2 Z-455 \text { ) which } \\
\text { has row to row spacing of } 20 \mathrm{~cm} \text { and } \\
\text { plant to plant spacing of } 10 \text { and } 12 \mathrm{~cm} \\
\text { was used. One dry and shallow tillage } \\
\text { using harrow/cultivator was followed } \\
\text { by planking. Prior to transplanting } \\
\text { field was provided a very light } \\
\text { irrigation and excess water was } \\
\text { drained out and the field was allowed } \\
\text { to settle for } 2 \text { days. }\end{array}$ & - & - & - \\
\hline
\end{tabular}

Field experiments and cultural practices

Field trials were conducted for four years from May 2014 to November 2017 in sub-tropical humid environment of eastern Tarai of Nepal. The cropping pattern was rice-Kidney bean-maize at Salbani and rice-wheat at rest of the locations. The growing seasons were May to Oct-Nov for rice and Nov to April for wheat for four nodes having rice-wheat cropping system. Likewise, the growing seasons were July to Oct-Nov for rice, Nov to March for Kidney bean and March-April to June-July for spring maize in Salbani. Crops variety and amount of fertilizers applied were consistent across the locations. The recommended dose of fertilizers required for irrigated condition were provided to experimented 
crops. In rice, wheat, maize and Kidney bean the amount of fertilizers applied were 100: 30: 30, 100: 50: 25, 120: 60: 40 and 40: 20: $20 \mathrm{~N}: \mathrm{P}_{2} \mathrm{O} 5: \mathrm{K}_{2} \mathrm{O}$ kg/ha respectively.

A tractor driven zero till seed drill multi planter that belongs to National Company from Ludhiana, India was used to sow rice, maize, wheat and Kidneybean seeds under zero/min till conditions. The machine allows 9 rows for rice and five rows for maize and is $180 \mathrm{~cm}$ wide. For unpuddled rice transplantation, A 4-row rice transplanter (Model: 2Z-455, walking type) was used.

\section{Statistical analysis}

Data entry and processing was carried out using Microsoft Office Excel 2016. Analysis of variance (ANOVA) and mean estimation were done with the software- $\mathrm{R}$ version 3.5.0. The treatment means were compared by the Least Significant Difference (LSD) test at 5\% level (Gomez and Gomez 1984, Shrestha 2019).

\section{RESULTS}

\section{Total nitrogen}

The total nitrogen (0-15 cm depth) varied significantly by tillage practices in Salbani, Bhaluwa and Kaptanganj (Table 4). Total nitrogen in soil changed significantly over the trial period in Salbani and Kaptanganj. In Salbani, the total N content under CT (T1) and ZT (T4) changed from 0.13 to $0.15 \%$ and 0.12 to $0.13 \%$ respectively (Table 9). The total $\mathrm{N}$ content under $\mathrm{CT}$ in trial period changed from 0.07 to $0.12,0.09$ to $0.10,0.10$ to 0.13 and 0.12 to $0.16 \%$ in Bhokraha, Simariya, Bhaluwa and Kaptanganj respectively. Under CT (T1), slight postitve change was revealed but under ZT (T3 and T4) very modest increment was showed in final year (Figure 4). Similarly, total N under ZT changed from 0.05 to $0.06 \%, 0.10$ to $0.12 \%, 0.10$ to $0.08 \%$ and 0.09 to $0.13 \%$ in Bhokraha, Simariya, Bhaluwa and Kaptanganj respectively. The wider range of total $\mathrm{N}$ in Treatment 3 was observed in Bhokraha $(0.02-0.12 \%)$ and Simariya (0.02-0.19\%) as compared to other locations while in second treatment where only rice was conventionally tilled, the total nitrogen in Salbani, Bhokraha, Simariya, Bhaluwa and Kaptanganj was changed by 13.3, 26, 20, 9.1 and $11.2 \%$ respectively. In all the treatments Bhaluwa showed the negative change in total $\mathrm{N}$ content over the trial period (Table 4).

Table 4. Total nitrogen (\%) status in five locations of Sunsari district

\begin{tabular}{|c|c|c|c|c|c|}
\hline Treatments & Salbani & Bhokraha & Simariya & Bhaluwa & Kaptanganj \\
\hline \multicolumn{6}{|l|}{ Years (Yr) } \\
\hline 2014 (Initial) & 0.12 & 0.07 & 0.09 & 0.11 & 0.10 \\
\hline 2015 & 0.13 & 0.06 & 0.10 & 0.10 & 0.12 \\
\hline 2016 & 0.14 & 0.07 & 0.13 & 0.09 & 0.14 \\
\hline 2017 & 0.14 & 0.10 & 0.11 & 0.10 & 0.14 \\
\hline $\mathrm{P}$ value & $<0.001$ & 0.09 & 0.29 & 0.31 & $<0.001$ \\
\hline LSD (0.05) & 0.01 & - & - & - & 0.02 \\
\hline $\operatorname{SEm}( \pm)$ & 0.003 & 0.01 & 0.04 & 0.01 & 0.01 \\
\hline \multicolumn{6}{|l|}{$\begin{array}{l}\text { Tillage } \\
\text { practices (TP) }\end{array}$} \\
\hline CTTPR-CT (T1) & 0.14 & 0.08 & 0.13 & 0.12 & 0.14 \\
\hline CTTPR-ZT (T2) & 0.14 & 0.08 & 0.14 & 0.11 & 0.14 \\
\hline UPTPR-ZT (T3) & 0.14 & 0.07 & 0.12 & 0.10 & 0.11 \\
\hline ZTDSR-ZT (T4) & 0.11 & 0.06 & 0.11 & 0.08 & 0.09 \\
\hline $\mathrm{P}$ value & $<0.001$ & 0.20 & 0.54 & $<0.001$ & $<0.001$ \\
\hline $\operatorname{LSD}(0.05)$ & 0.01 & - & - & 0.01 & 0.01 \\
\hline $\operatorname{SEm}( \pm)$ & 0.004 & 0.01 & 0.04 & 0.01 & 0.01 \\
\hline \multicolumn{6}{|l|}{$\begin{array}{l}\text { Interaction } \\
(\mathbf{Y r} \times \mathbf{T P})\end{array}$} \\
\hline $\mathrm{P}$ value & 0.007 & 0.97 & 0.68 & 0.24 & 0.84 \\
\hline LSD (0.05) & 0.02 & - & - & - & - \\
\hline $\operatorname{SEm}( \pm)$ & 0.007 & 0.03 & 0.09 & 0.01 & 0.02 \\
\hline $\mathrm{CV}(\%)$ & 6.72 & 23.5 & 19.1 & 16.77 & 17.44 \\
\hline
\end{tabular}


$* * *$ significant at $p<0.001, * *$ Highly significant at $p<0.01, \quad N S=$ Non-significant. CT: Conventional tillage, ZT: Zero tillage, CTTPR: Conventional tillage+Transplanted rice, UPTPR: Unpuddled+Transplanted rice, ZTDSR: Zero tillage+Direct seeded rice.

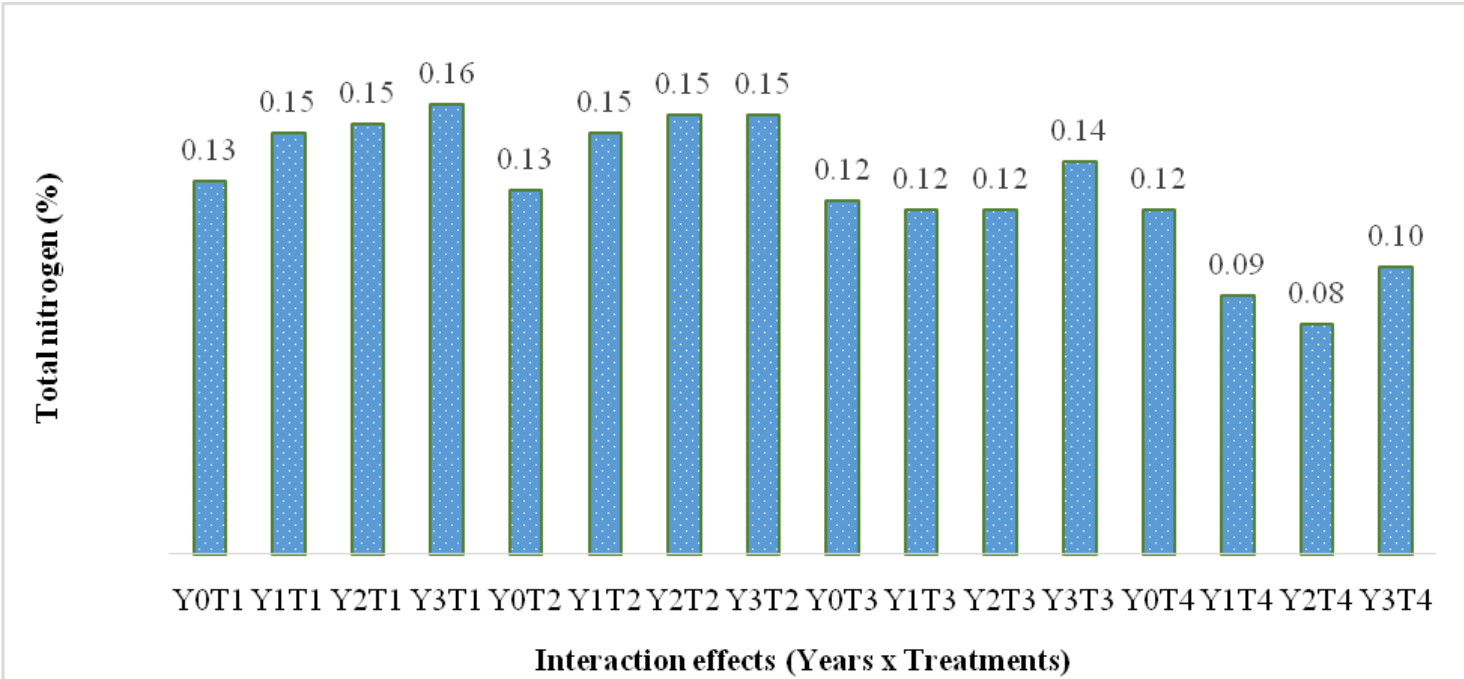

Figure 4. Change in total nitrogen in different tillage practices over the trial period in Salbani, Sunsari.

Y0: before beginning of trial; Y1, Y2 and Y3: subsequent years; T: treatments

Available phosphorus

The available phosphorus $(0-15 \mathrm{~cm}$ depth) varied significantly over the trial period in the locations except Kaptanganj. Tillage practices had no significant effect in Bhokraha (Table 5). Available phosphorus under CT (T1) in trial period changed from 105.2 to 115.3, 72.3 to 99.0, 56.9 to $71.0,86.4$ to 93.9 and 80.1 to $78.9 \mathrm{mg} / \mathrm{kg}$ in Salbani, Bhokraha, Simariya, Bhaluwa and Kaptanganj respectively (Table 9). Similarly, under ZT (T4) it changed from 108.8 to $113.7,74.6$ to $78.9,66.0$ to $86.1,83.6$ to 79.7 and 77.0 to $77.1 \mathrm{mg} / \mathrm{kg}$ respectively in the above mentioned locations (Table 9). The mean value of available phosphorus was the highest in Salbani followed by Bhaluwa. The treatment where only rice plot was conventionally tilled (T2) showed significant change in available phosphorus in the locations except Bhokraha. The treatment where rice was transplanted in unpuddled condition and zero tilled for the rest crops (T3) has mean value 107.1, 83.1, 77.1, 91.1 and $78.2 \mathrm{mg} / \mathrm{kg}$ available phosphorus in Salbani, Bhokraha, Simariya, Bhaluwa and Kaptanganj respectively (Table 5).

Table 5. Available phosphorus (mg/kg soil) in five locations of Sunsari district

\begin{tabular}{|c|c|c|c|c|c|}
\hline Treatments & Salbani & Bhokraha & Simariya & Bhaluwa & Kaptanganj \\
\hline \multicolumn{6}{|l|}{ Years (Yr) } \\
\hline 2014 (Initial) & 105.8 & 75.1 & 62.2 & 84.9 & 82.1 \\
\hline 2015 & 108.6 & 81.7 & 71.9 & 90.1 & 83.4 \\
\hline 2016 & 110.4 & 85.6 & 76.9 & 92.0 & 83.6 \\
\hline 2017 & 112.8 & 93.3 & 78.2 & 91.5 & 82.7 \\
\hline$P$ value & $<0.001$ & 0.003 & 0.004 & $<0.001$ & 0.98 \\
\hline $\operatorname{LSD}(0.05)$ & 2.41 & 8.87 & 8.93 & 2.88 & - \\
\hline $\operatorname{SEm}( \pm)$ & 1.06 & 3.89 & 3.91 & 1.26 & 3.33 \\
\hline \multicolumn{6}{|c|}{ Tillage practices (TP) } \\
\hline CTTPR-CT (T1) & 109.8 & 84.0 & 64.5 & 93.4 & 80.7 \\
\hline CTTPR-ZT (T2) & 108.3 & 85.6 & 67.2 & 92.5 & 85.5 \\
\hline UPTPR-ZT (T3) & 107.1 & 83.1 & 77.1 & 91.1 & 88.8 \\
\hline ZTDSR-ZT (T4) & 110.2 & 79.1 & 75.7 & 79.9 & 78.2 \\
\hline $\mathrm{P}$ value & 0.02 & 0.41 & 0.006 & 0.008 & 0.02 \\
\hline $\operatorname{LSD}(0.05)$ & 2.15 & - & 7.91 & 2.58 & 6.81 \\
\hline $\operatorname{SEm}( \pm)$ & 1.18 & 4.35 & 4.38 & 1.41 & 3.73 \\
\hline \multicolumn{6}{|c|}{ Interaction (Yr x TP) } \\
\hline$P$ value & 0.76 & 0.85 & 0.99 & 0.004 & 0.98 \\
\hline $\operatorname{LSD}(0.05)$ & - & - & - & 5.78 & - \\
\hline $\operatorname{SEm}( \pm)$ & 2.36 & 8.69 & 8.75 & 2.82 & 7.46 \\
\hline
\end{tabular}




\begin{tabular}{lccccc}
\hline $\mathrm{CV}(\%)$ & 2.65 & 12.83 & 15.06 & 3.87 & 10.96 \\
\hline$* * *$ significant at $p<$ & $0.001, * *$ & Highly & significant at $p<0.01$, & $*$ significant at $p<0.05$, NS $=$ Non-significant. & CT: \\
Conventional tillage, ZT: Zero tillage, CTTPR: Conventional tillage+Transplanted rice, & UPTPR: Unpuddled+Transplanted \\
rice, ZTDSR: Zero tillage+Direct seeded rice.
\end{tabular}

\section{Available potassium}

The available potassium $(0-15 \mathrm{~cm}$ depth) varied significantly over the trial period in the locations except Kaptanganj. Tillage practices had no significant effect in Simariya (Table 6). In both CT and ZT conditions the mean value of available potassium is greater than phosphorus in Kaptanganj only (Table 5 and 6). Available potassium under CT (T1) in trial period changed from 64.3 to 78.5, 71.5 to $73.8,64.0$ to $73.7,72.6$ to 80.3 and 109.6 to $114.4 \mathrm{mg} / \mathrm{kg}$ in Salbani, Bhokraha, Simariya, Bhaluwa and Kaptanganj respectively (Table 9). Similarly, under ZT (T4) it changed from 68.4 to 73.3, 77.5 to $82.6,76.6$ to $81.6,82.2$ to 82.6 and 98.1 to $114.1 \mathrm{mg} / \mathrm{kg}$ respectively in the above mentioned locations. Salbani revealed a notable positive status of potassium balance. The mean value of available potassium was the highest in Kaptanganj followed by Salbani. The treatment where only rice plot was conventionally tilled (T2) showed significant change in available potassium in the locations except Kaptanganj. The treatment where rice was transplanted in unpuddled condition and zero tilled for subsequent crops (T3) has mean value 68.5, 79.4, 66.2, 82.2 and $113.2 \mathrm{mg} / \mathrm{kg}$ available potassium in Salbani, Bhokraha, Simariya, Bhaluwa and Kaptanganj respectively (Table 6).

Table 6. Available potassium(mg/kg soil) in five locations of Sunsari district

\begin{tabular}{|c|c|c|c|c|c|}
\hline Treatments & Salbani & Bhokraha & Simariya & Bhaluwa & Kaptanganj \\
\hline \multicolumn{6}{|l|}{ Years (Yr) } \\
\hline 2014 (Initial) & 66.5 & 72.1 & 58.3 & 77.5 & 107.1 \\
\hline 2015 & 69.1 & 77.8 & 63.1 & 83.1 & 114.1 \\
\hline 2016 & 73.7 & 75.9 & 62.0 & 80.7 & 109.7 \\
\hline 2017 & 75.5 & 73.5 & 62.8 & 78.8 & 108.7 \\
\hline$P$ value & $<0.001$ & $<0.001$ & 0.002 & $<0.001$ & 0.49 \\
\hline $\operatorname{LSD}(0.05)$ & 2.37 & 3.33 & 9.21 & 3.14 & - \\
\hline $\operatorname{SEm}( \pm)$ & 1.04 & 1.46 & 4.03 & 1.38 & 6.10 \\
\hline \multicolumn{6}{|c|}{ Tillage practices (TP) } \\
\hline CTTPR-CT (T1) & 71.3 & 74.8 & 68.6 & 77.1 & 110.2 \\
\hline CTTPR-ZT (T2) & 72.3 & 79.6 & 67.8 & 82.8 & 116.7 \\
\hline UPTPR-ZT (T3) & 68.5 & 79.4 & 66.2 & 82.2 & 113.2 \\
\hline ZTDSR-ZT (T4) & 70.4 & 73.8 & 72.7 & 81.3 & 104.7 \\
\hline $\mathrm{P}$ value & 0.008 & $<0.001$ & 0.44 & 0.001 & 0.27 \\
\hline $\operatorname{LSD}(0.05)$ & 2.04 & 2.98 & - & 2.81 & - \\
\hline $\operatorname{SEm}( \pm)$ & 1.16 & 1.63 & 4.51 & 1.54 & 6.82 \\
\hline \multicolumn{6}{|l|}{$\begin{array}{l}\text { Interaction } \\
(\text { Yr x TP) }\end{array}$} \\
\hline $\mathrm{P}$ value & 0.02 & 0.96 & 0.95 & 0.48 & 1.00 \\
\hline $\operatorname{LSD}(0.05)$ & 4.74 & - & - & - & - \\
\hline $\operatorname{SEm}( \pm)$ & 2.32 & 3.26 & 9.02 & 3.08 & 13.63 \\
\hline CV $(\%)$ & 4.02 & 5.21 & 16.03 & 4.66 & 15.01 \\
\hline
\end{tabular}

\section{Soil pH}

In Bhokraha and Simariya, soil pH was significantly affected by tillage practices (Table 7). In Salbani, Bhokraha and Bhaluwa soil $\mathrm{pH}$ was significantly changed over the trial period. The soil $\mathrm{pH}$ of all locations were strongly to slightly acidic (USDA ratings). The change in soil $\mathrm{pH}$ under CT (1) was 5.8 to $6.6,5.8$ to $5.5,6.1$ to 5.6, 5.8 to 5.5 and 5.7 to 5.5 in Salbani, Bhokraha, Simariya, Bhaluwa and Kaptanganj respectively (Table 9). The initial soil pH under ZT (T4) was 5.9 to 6.7, 5.7 to 5.7, 5.8 to $6.5,5.8$ to 6.1 and 5.5 to 5.7 in Salbani, Bhokraha, Simariya, Bhaluwa and Kaptanganj respectively. The treatment where only rice plot is conventionally tilled (T2) showed the ranges 4.7- 
7.1, 5.0-7.1, 5.1-6.7, 5.0-6.8 and 5.0-6.5 in Salbani, Bhokraha, Simariya, Bhaluwa and Kaptanganj respectively. The narrower $\mathrm{pH}$ fluctuation was observed in ZT in the locations except Simariya as compared to CT. The treatment where rice was transplanted in unpuddled condition and zero tilled for subsequent crops (T3) has $\mathrm{pH}$ ranges 4.8-6.7, 5.0-6.8, 5.3-6.8, 5.1-6.8, 4.3-6.1 in Salbani, Bhokraha, Simariya, Bhaluwa and Kaptanganj respectively (Table 7).

Table 7. Soil pH in five locations of Sunsari district

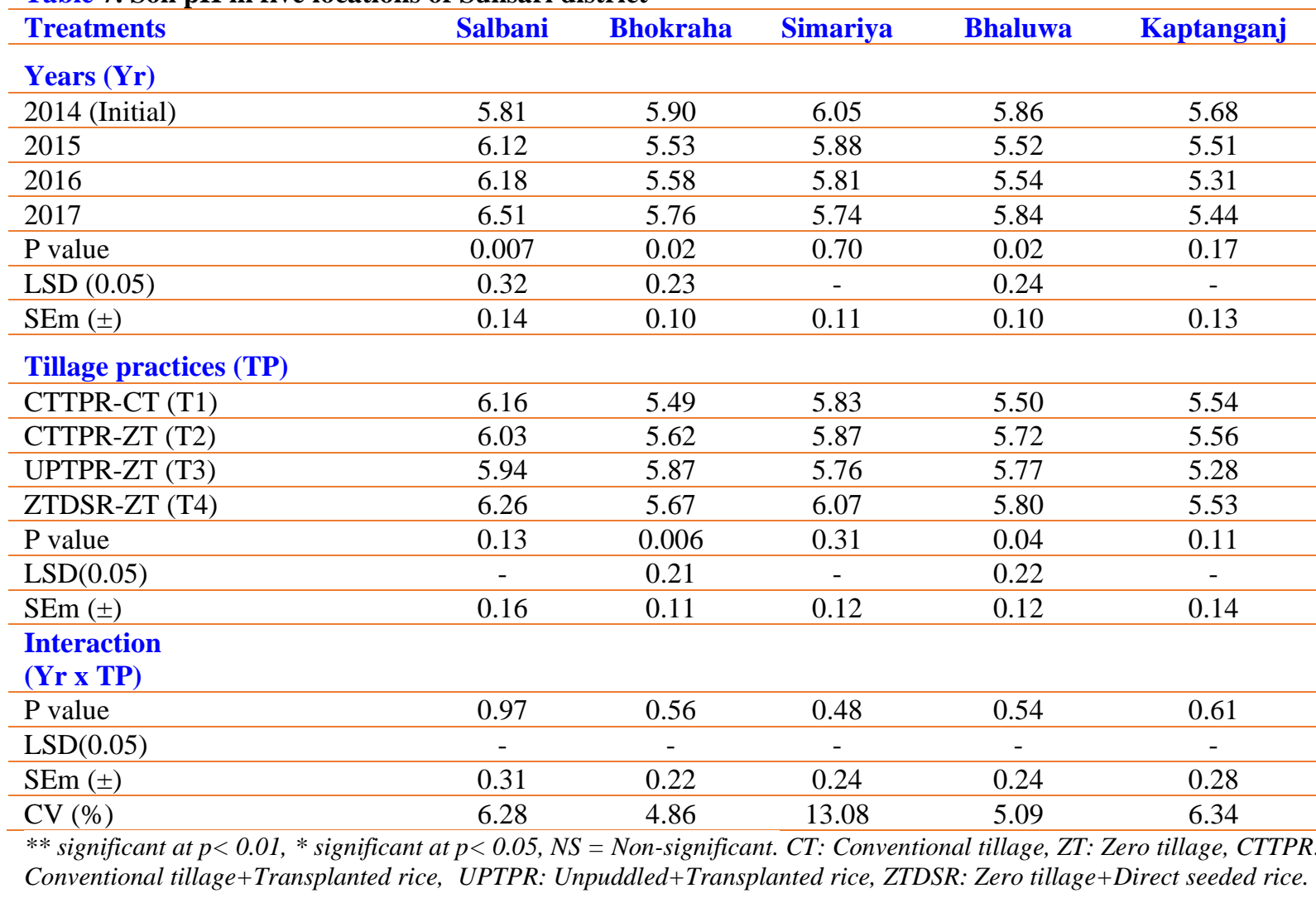

\section{Soil organic matter}

The soil organic matter $(0-15 \mathrm{~cm}$ depth) varied significantly over the trial period in three locations Salbani, Bhokraha and Kaptanganj. Tillage practices had significant effect in all locations except Kaptanganj (Table 8). Soil organic matter under CT (T1) in trial period changed from 3.5 to 3.3, 2.6 to 2.5 and 2.5 to $2.3 \%$ in Salbani, Bhokraha and Kaptanganj respectively (Table 9). Similarly, under ZT (T4) it changed from 3.7 to $3.8,2.3$ to $2.6,2.2$ to $2.4,2.5$ to 2.2 and 2.3 to $2.5 \%$ respectively in the above mentioned locations. The mean value of available potassium was highest in Salbani followed by Kaptanganj and Bhokraha. The treatment where only rice plot is conventionally tilled (T2) showed significant change in soil organic matter in all the locations except Kaptanganj (Table 8). The treatment where rice was transplanted in unpuddled condition and zero tilled for subsequent crops (T3) has mean value 3.73, 2.06, 2.44, 2.25 and 2.33\% soil organic matter in Salbani, Bhokraha, Simariya, Bhaluwa and Kaptanganj respectively (Table 8).

Table 8. Soil organic matter (\%) content in five locations of Sunsari district

\begin{tabular}{lccccc}
\hline Treatments & Salbani & Bhokraha & Simariya & Bhaluwa & Kaptanganj \\
\hline Years (Yr) & & & & & \\
\hline 2014 (Initial) & 3.41 & 2.15 & 2.22 & 2.43 & 2.36 \\
\hline 2015 & 3.53 & 2.22 & 2.21 & 2.25 & 2.21 \\
\hline 2016 & 3.61 & 2.21 & 2.34 & 2.22 & 2.18 \\
\hline 2017 & 3.82 & 2.47 & 2.37 & 2.35 & 2.46 \\
\hline P value & 0.004 & 0.03 & 0.14 & 0.06 & 0.01 \\
\hline LSD $(0.05)$ & 0.22 & 0.24 & - & - & 0.17 \\
\hline SEm $( \pm)$ & 0.09 & 0.12 & 0.08 & 0.07 & 0.08 \\
\hline
\end{tabular}




\begin{tabular}{|c|c|c|c|c|c|}
\hline Treatments & Salbani & Bhokraha & Simariya & Bhaluwa & Kaptanganj \\
\hline \multicolumn{6}{|c|}{ Tillage practices (TP) } \\
\hline CTTPR-CT (T1) & 3.31 & 2.38 & 2.18 & 2.45 & 2.35 \\
\hline CTTPR-ZT (T2) & 3.68 & 2.11 & 2.21 & 2.35 & 2.23 \\
\hline UPTPR-ZT (T3) & 3.73 & 2.06 & 2.44 & 2.25 & 2.33 \\
\hline ZTDSR-ZT (T4) & 3.52 & 2.34 & 2.23 & 2.23 & 2.27 \\
\hline$P$ value & $<0.001$ & 0.009 & 0.009 & 0.01 & 0.34 \\
\hline $\operatorname{LSD}(0.05)$ & 0.18 & 0.22 & 0.16 & 0.14 & - \\
\hline $\operatorname{SEm}( \pm)$ & 0.11 & 0.12 & 0.09 & 0.08 & 0.07 \\
\hline \multicolumn{6}{|l|}{$\begin{array}{l}\text { Interaction } \\
\text { (Yr x TP) }\end{array}$} \\
\hline $\mathrm{P}$ value & 0.39 & 0.82 & 0.25 & 0.70 & 0.47 \\
\hline $\operatorname{SEm}( \pm)$ & 0.21 & 0.24 & 0.18 & 0.15 & 0.16 \\
\hline $\mathrm{CV}(\%)$ & 7.31 & 13.08 & 9.47 & 8.16 & 8.77 \\
\hline
\end{tabular}

Table 9. Change in soil parameters under CT and ZT practices in four years (2014-2017) at five locations of Sunsari district

\begin{tabular}{|c|c|c|c|c|c|c|c|c|c|c|c|}
\hline \multirow[t]{2}{*}{ Locations } & \multirow[t]{2}{*}{$\begin{array}{l}\text { Tillage } \\
\text { practices }\end{array}$} & \multicolumn{2}{|c|}{$\begin{array}{c}\text { Total Nitrogen } \\
(\%)\end{array}$} & \multicolumn{2}{|c|}{$\begin{array}{c}\text { Avail } \mathrm{P}_{2} \mathrm{O}_{5} \\
(\mathrm{mg} / \mathrm{kg})\end{array}$} & \multicolumn{2}{|c|}{$\begin{array}{c}\text { Avail } \mathrm{K}_{2} \mathrm{O} \\
(\mathrm{mg} / \mathrm{kg})\end{array}$} & \multicolumn{2}{|c|}{ Soil pH } & \multicolumn{2}{|c|}{$\begin{array}{c}\text { Soil organic } \\
\text { matter }(\%)\end{array}$} \\
\hline & & Initial & $\begin{array}{l}\text { Final } \\
\text { year }\end{array}$ & Initial & $\begin{array}{l}\text { Final } \\
\text { year }\end{array}$ & Initial & $\begin{array}{l}\text { Final } \\
\text { year }\end{array}$ & Initial & $\begin{array}{l}\text { Final } \\
\text { year }\end{array}$ & Initial & $\begin{array}{l}\text { Final } \\
\text { year }\end{array}$ \\
\hline \multirow{2}{*}{ Salbani } & CT (T1) & 0.13 & 0.15 & 105.18 & 115.3 & 64.26 & 78.50 & 5.79 & 6.6 & 3.46 & 3.26 \\
\hline & $\mathrm{ZT} \mathrm{(T4)}$ & 0.12 & 0.13 & 108.76 & 113.73 & 68.53 & 73.33 & 5.8 & 6.7 & 3.70 & 3.76 \\
\hline \multirow{2}{*}{ Bhokraha } & CT (T1) & 0.07 & 0.12 & 72.29 & 98.97 & 71.48 & 73.83 & 5.7 & 5.5 & 2.63 & 2.51 \\
\hline & $\mathrm{ZT} \mathrm{(T4)}$ & 0.05 & 0.06 & 74.64 & 78.90 & 77.46 & 82.64 & 5.8 & 5.7 & 2.29 & 2.57 \\
\hline \multirow{2}{*}{ Simariya } & $\mathrm{CT}$ (T1) & 0.09 & 0.10 & 56.93 & 70.99 & 64.04 & 73.74 & 6.1 & 5.5 & 2.23 & 2.15 \\
\hline & ZT (T4) & 0.10 & 0.12 & 65.99 & 86.03 & 76.61 & 81.59 & 5.8 & 6.5 & 2.2 & 2.44 \\
\hline \multirow{2}{*}{ Bhaluwa } & CT (T1) & 0.10 & 0.13 & 86.36 & 93.92 & 72.57 & 80.33 & 5.7 & 5.5 & 2.54 & 2.47 \\
\hline & $\mathrm{ZT} \mathrm{(T4)}$ & 0.10 & 0.08 & 83.63 & 79.68 & 82.21 & 82.64 & 5.8 & 6.1 & 2.45 & 2.24 \\
\hline \multirow{2}{*}{ Kaptanganj } & CT (T1) & 0.12 & 0.16 & 80.10 & 78.87 & 109.64 & 114.37 & 5.8 & 5.5 & 2.48 & 2.31 \\
\hline & $\mathrm{ZT} \mathrm{(T4)}$ & 0.09 & 0.13 & 76.96 & 77.08 & 98.06 & 114.06 & 5.5 & 5.7 & 2.25 & 2.47 \\
\hline
\end{tabular}

CT: Conventional tillage, ZT: Zero tillage.

\section{DISCUSSION}

Among many findings few that seemed important were discussed with scientific support in this section. In conventionally tilled condition the total nitrogen content in soil in final year was higher than initial year in all the locations except Bhaluwa. The dose of $\mathrm{N}$ which farmers had been applied since long was quite low as compared to recommended dose we provided for the trial (Annual reports, SRFSI). This could be the reason behind the fact. In ZT, the total nitrogen in the first three years showed slow decreasing trend and exhibited slight increase in the final year in both rice-wheat and rice-kidney bean-maize cropping system. This could be due to the nitrogen within the residue usually remains tied up or immobilized until decomposition is complete and released by soil microbes in slow process through mineralization. Same was the findings for the changes observed in available phosphorus and potassium during the trial period. The trial conducted plots at Bhaluwa was more vulnerable to nitrogen losses as favored by excessive runoff under the conventional tillage system in that particular area. So the $\mathrm{N}$ balance at Bhaluwa appeared to be negative. Furthermore, higher percolation might have promoted this process especially under conditions of uncontrolled irrigation and drainage system and excess rainfall. A greater SOC loss by emission from conventionally tilled plot as compared to reduced form of tillage seems possible because this environment looks very conducive for accelerated microbial oxidation of organic matter under high summer temperatures of this sub-tropical region. This situation have helped higher organic carbon stocks on no-tillage plots in all locations. A concrete idea of it could be obtained from Lal 2004 who suggested the possibility of a wide range of seasonal carbon emissions from tillage operations $(2-15 \mathrm{~kg} / \mathrm{ha})$ and emission reduction 
from no-till operation (30-35 kg/ha) on croplands. Campbell et al 1996 has also advocated that the amount of crop residue returned to soil was positively related with soil organic carbon in a clay soil. It is also likely that the relatively greater crop residue retention in ZT, especially on acidic soils, will contribute to further acidification by producing acids or acidic products during organic matter decomposition (Dalal et al 1991). Different tillage practices in rice-wheat cropping system in Bhokraha did not affect available phosphorus (Table 4), possibly due to lower P dissolution resulting from the higher $\mathrm{pH}$. Phosphorus imbalances in croplands occur in the long term (MacDonald et al 2011), the short term effects of changing tillage practices on available phosphorus is less clear. In all locations, most notably Kaptanganj have soil acidity majorly concentrated in ZT plots. Higher N rate and the removal of greater quantity of non-acidic cations through grain and stubble/straw removal tended to lower $\mathrm{pH}$ in the soil under ZT compared to CT. The fact can be justified from Thomas et al 2007 and Guo et al 2010. Conversely, total nitrogen and organic matter tended to be higher in soil under ZT in the final year though slight decrease observed in first three years, primarily because of crop residue input and slow mineralization. In rice-kidney bean-maize cropping system in Salbani and rice-wheat cropping system in rest of the locations available potassium balance is satisfactory because of application of recommended dose of fertilizer during the trial period but in Salbani the loss is more than rest of the locations, due primarily to larger $\mathrm{K}$ removal in the maize crop than the wheat. In Salbani, better increment of soil organic matter, phosphorus and potassium was observed under CT as compared to ZT due to the return of whole maize stubble to soil before transplantation of rice, which significantly contributed to addition of these nutrients. In all locations like nitrogen and phosphorus, potassium had a constant or positive balance in all the treatments. But the trend of not applying the source of potassium is major concern in all the locations. The deficiency of $\mathrm{K}$ and limitation of this nutrient element was revealed by many research works including the study in crop yield responses to additions of $\mathrm{K}$ and $\mathrm{Zn}$ when evaluated through a series of trials in the Tarai of Nepal (Duxbury 2001). Responses to $\mathrm{K}$ and/or $\mathrm{Zn}$ were observed for both rice and wheat, but these varied as a function of soil texture and between years. The soil under ZT found containing less available K than CT at Regional Agricultural Research Station, Tarahara (Sinha et al 2019). Furthermore, negative K balance for crops in South Asia is widespread (Singh et al 2005, Surekha and Satishkumar 2014).

\section{CONCLUSION}

The sustainable productivity of cereal-based cropping system depends on proper use and sustainable conservation of soil. The CA-based practices: ZT, crop residue retention and crop rotation has improved soil organic matter content in all locations. Some notable threats of soil acidification, majorly in sandy loam dominant Kaptanganj and negative soil organic matter balance in majority of locations under conventional tillage should be placed in high alert. Increased use of ammonium-N and lack of inclusion of legume in cereal-based cropping system can intensify the problem. The imbalances in available phosphorus content is also widespered but the fluctuation under ZT is narrower as compared to CT. The duration seemed short for in-depth study of soil properties. More comprehensive and long-term study can further clarify the overall chemical and physical dynamics of soil properties.

\section{ACKNOWLEDGEMENTS}

The research was conducted as part of a project 'Sustainable and Resilient Farming Systems Intensification in Eastern Gangatic Plains-SRFSI' funded by the Australian Center for International Agricultural Research (ACIAR) with support of Nepal Agricultural Research Council (NARC) and Department of Agriculture (DoA). Authors were grateful to International Maize and Wheat Improvement Center (CIMMYT) for technical support. The authors acknowledged the help and assistance provided by the farmers and field technicians.

\section{REFERENCES}

Bouyoucos GJ. 1962. Hydrometer method improved for making particle size analyses of soils. Agronomy Journal 54 (5): 464-465.

Bremner JM and CS Mulvaney. 1982. Nitrogen total. In: A. L. Page (ed.), Methods of soil analysis. Agron. No. 9, Part 2: Chemical and microbiological properties. 2nd edition. Am. Soc. Agron., WI, USA; pp. 595-624. 
Campbell CA, BG McConkey, RP Zentner, F Selles and D Curtin. 1996. Long term effects of tillage and crop rotations on soil organic $\mathrm{C}$ and total $\mathrm{N}$ in a clay soil in southwestern Saskatchewan. Canadian Journal of Soil Science 76: 395-401.

Choudhary M, HS Jat, A Datta, AK Yadav, TB Sapkota, S Mondal, RP Meena, PC Sharma and ML Jat. 2018. Sustainable intensification influences soil quality, biota, and productivity in cereal-based agro-ecosystems. Applied Soil Ecology 126: 189-198. DOI: http://10.1016/j.apsoil.2018.02.027

Dalal RC, PA Henderson and JM Glasby. 1991. Organic matter and microbial biomass in a Vertisol after $20 \mathrm{yr}$ of zero tillage. Soil Biology and Biochemistry 23: 435-441.

Duxbury JM. 2001. Annual Report for Sustainability of Post-Green Revolution Agriculture: The Rice-Wheat Cropping System of South Asia; p.6.

FAO. 2000. Conservation tillage: The end of the plough? www.fao.org/

Gathala MK, ML Jat, YS Saharawat, SK Sharma, Y Singh and JK Ladha. 2017. Physical and chemical properties of a sandy loam soil under irrigated rice-wheat sequence in the Indo-Gangetic Plains of South Asia. Journal of Ecosystem and Echography 7: 1-10.

Gathala MK. 2018. Sustainable and resilient farming systems intensification in the Eastern Gangetic Plains (SRFSI). A synthesis report. CSE/2011/077, Australian Centre for International Agricultural Research: Canberra ACT.

Gomez KA and AA Gomez. 1984. Statistical Procedure for Agricultural Research(2nd edn.). Int. Rice Res. Inst. andWilley, New York; pp. 28-192.

Guo JH, XJ Liu, Y Zhang, JL Shen, WX Han, WF Zhang, PChristie, K Goulding, PM Vitousek and FS Zhang. 2010. Significant acidification in major Chinese croplands. Science 327: 1008-1010.

Hobbs PR and RK Gupta. 2004. Problems and challenges of no-till farming for the rice-wheat systems of the IndoGangetic Plains in South Asia. In: R Lal, P Hobbs, N Uphoff, and DO Hansen (eds.), Sustainable Agriculture and the Rice-Wheat System. Columbus, Ohio, and New York, USA: Ohio State University and Marcel Dekker, Inc.; pp. 101-19.

Islam S, MK Gathala, TP Tiwari, J Timsina, AM Laing, S Maharjan, AK Chowdhury, PM Bhattacharya, T Dhar, B Mitra, S Kumar, PK Srivastwa, SK Dutta, R Shrestha, S Manandhar, SR Shrestha, P Paneru, NA Siddquie, A Hossain, R Islam, AK Ghosh, MA Rahman, U Kumar, KK Rao and B Gérard. 2019. Conservation Agriculture based Sustainable Intensification: Increasing Yields and Water Productivity for Smallholders of the Eastern Gangetic Plains. Field Crops Research 238: 1-17.

Jackson ML. 1973. Soil Chemical Analysis. Pentice Hall of India Pvt. Ltd., New Delhi.

Jackson ML. 1967. Handling soil samples in the laboratory. In: Soil chemical analysis. Prentice hall of India, Pvt. Ltd., New Delhi 2: 30-37.

Karki TB and J Shrestha. 2015. Should we go for conservation agriculture in Nepal? International Journal of Global Science Research 2 (4): 271-276.

Karlen DL, CA Ditzer and SS Andrews. 2003. Soil quality: why and how? Geoderma 114: 145-156.

Lal R. 2004. Soil carbon sequestration impacts on global climate change and food security. Science 34:16231627.

MacDonald GK, EM Bennett, PA Potter and N Ramankutty. 2011. Agronomic phosphorus imbalances across the world's croplands. Proceedings of the National Academy of Sciences of the United States of America 108: 3086-3091.

Mandal SK, R Kumar, A Kumar, S Kumar, YK Singh and R Kumar. 2015. Impact of resource conservation technologies on soil health and productivity of wheat in rice-wheat cropping system. Journal of Applied and Natural Science 7(1): 58-66.

Olsen SR, CV Cole and LA Dean. 1954. Estimation of available phosphorus in soil by extraction with sodium carbonate. In: Method of soil analysis, Part 2. (CA Black, ed) American Soc. Agron. Inc, Medison, USA; pp. 1044-1046.

RARS. 2016. Long term soil fertility experiment in rice-wheat system at RARS, Tarahara. In: Annual report20015/16. Regional Agricultural Research Station (RARS) - Nepal Agricultural Research Council, Tarahara, Sunsari; pp.18-21.

Shrestha J. 2019. P-Value: A true test of significance in agricultural research. Retrieved from https://www.linkedin.com/pulse/p-value-test-significance-agricultural-research-jiban-shrestha/

Singh Y, B Singh and J Timsina. 2005. Crop residue management for nutrient cycling and improving soil productivity in the rice-based cropping systems in the tropics. Advances in Agronomy 85: 269-407.

Sinha AK, A Gosh, T Dhar, PM Bhattacharya, B Mitra, S Rakesh, P Paneru, SR Shrestha, S Manandhar, K Beura, S Dutta, AK Pradhan, KK Rao, Akbar Hossain, N Siddquie, SH Molla, AK Chaki, MK Gathala, MS Islam, RC Dalal, DS Gaydon, AM Laing and NW Menzies. 2019. Trends in key soil parameters under conservation agriculture-based sustainable intensification farming practices in the Eastern Ganga Alluvial Plains. Soil Research. CSIRO publishing. http://doi.org/10.1071/SR19162 
Surekha K and YS Satishkumar. 2014. Productivity, nutrient balance, soil quality and sustainability of rice (Oryza sativa L.) under organic and conventional production systems. Communications in Soil Science and Plant Analysis 45: 415-428.

Thomas GA, RC Dalal and J Standley. 2007. No-till effects on organic matter, pH, cation exchange capacity and nutrient distribution in a Luvisol in the semi-arid subtropics. Soil and Tillage Research 94: 295-304.

Walkley AJ and IA Black. 1934. Estimation of soil organic carbon by the chromic acid titration method. Soil Science 37 (1): 29-38.

Wanjari RH, MV Singh and PK Ghosh. 2004. Sustainable yield index: An approach to evaluate sustainability of long-term intensive cropping systems in India. Journal of Sustainable Agriculture 24:39-56. DOI: http://doi.org/10.1300/J064v24n04-05

||------||------|-1| 